\title{
Socialization of the Benefits of Fermenting Cattle Milk into Yogurt as a Probiotic Food Product for Housewife Community of Sruni Village, Musuk, Boyolali
}

\author{
Sri Sinto Dewi ${ }^{1}$, Stalis Norma Ethica ${ }^{2}$, Wikanastri Hersoelistyorini ${ }^{3}$ \\ 1, 2, 3 Universitas Muhammadiyah Semarang
}

\begin{abstract}
Article History ABSTRACT
Received 06.08.2019

Received in revised form 28.09.2019

Accepted 02.12.2019

Available online 16.12.2019

Boyolali Regency is among districts in Indonesia, which still has poverty issues and receives direct cash assistance from the government. Yet, villages of the regency including Sruni at Musuk sub-district has been known as one of the main producers of fresh cow milk for the Central Java region.There has been no attempt to process fresh milk into food products of higher economic value at Sruni Village. Meanwhile, results of the strengths, weaknesses, opportunities, and threats (SWOT) analysis at Musuk showed that the region has the potential to be developed for dairy industry. Therefore, through socialization program, community empowerment should be initiated by socializing benefits of fermenting cattle milk into yogurt as a probiotic food product. The socialization had been carried out for 12 housewives in the village of Sruni through two smallclass seminars in April 2019. Evaluation was conducted by comparing the number of correct answers from participants' answers recorded on questionnaire given prior and after each of both seminars. Percentage of improved answers were presented in histograms and then analyzed. As results, the first seminar produced in average $47.4 \%$ improved answers, while the second seminar could generate in average $27.3 \%$ improved answers. The results showed that in general, the conducted socialization program was quite successful in improving understanding of Sruni villagers on the benefits of fermenting cattle milk into yogurt as a probiotic food product.

KEYWORDS: Cattle Milk, Housewife Community, Socialization Program, Sruni Village, Yogurt Probiotics.
\end{abstract} Attribution 4.0 International License, which permits unrestricted use, distribution, and reproduction in any medium, provided the original work is properly cited. ๑ 2019 Sri Sinto Dewi, Stalis Norma Ethica, Wikanastri Hersoelistyorini.

\section{INTRODUCTION}

Based on BPS data published in March 2018, Indonesia reached the lowest point in terms of the percentage of poverty since 1999 , which amounted to $9.82 \%$, equivalent to 25.95 million people. Among factors influencing the success of the reduction in poverty

${ }^{3}$ Corresponding author: Faculty of Nursing and Health Sciences, Universitas Muhammadiyah Semarang, Jl. Kedungmundu Raya No. 18 Semarang, 50273, Indonesia. Email: wikanastri@ unimus.ac.id 
levels include an increase in cash social assistance in the first quarter of 2018 which grew by $87.6 \%$ compared to the first quarter of 2017 which only grew by $3.39 \%$ (Putera, 2018). Other factors that are believed to be influential in reducing poverty are the existence of non-cash food assistance programs that are channeled on time (Kurniawati, 2017; Putera, 2018; Rachman \& Agustian, 2018). The government's success in reducing poverty in 2018 is necessary and must be supported by the sustainability of community empowerment programs.

Boyolali Regency is a district in Indonesia that has poverty problems (Dewi, 2016; Suswadi \& Sutarno, 2018). According to data from the Poverty Alleviation Committee, the number of households in Boyolali Regency is 248,549 units, $38.26 \%$ (95,083 units) are classified as poor and receive direct cash assistance from the government (Astuti \& Musiyam, 2009).

Apart from the existing poverty problems, Boyolali Regency has been known as an important center of dairy farming in Indonesia and is a producer of fresh cow milk for the Central Java region (Wicaksono \& Sudarwanto, 2017; Retnaningsih \& Basuki, 2017; Kartika, 2017; Nurtini \& Anggriani UM, 2018). From various villages producing cow milk found in Boyolali Regency, Sruni Village is a village whose contribution to the income of its dairy cow milk business to the total household income has not been significant (Herawati, 2013). For example, the contribution of income for dairy cattle business in Sruni Village is only $43.72 \%$ of the total household income even though in other villages such as Singosari Village the contribution has reached 71.60\% (Ningrum, 2016).

Sruni Village is among villages located in Musuk District, Boyolali Regency (Figure 1), Central Java. Sruni Village in Musuk Sub-district consists of 27 RTs and belongs to RW 1-5. As a partner the PKM program is a group of housewives from RW 4, Sruni Musuk Village, Boyolali, which are as many as 10 people (dasa wisma or Dawis). The partner's educational background is elementary school graduates. At present, to help husbands in sustaining the family economy, these mothers help to manage the farm by looking for grass for animal feed. Partner families including simple families. Given the economic limitations and knowledge and strategic potential of partners to increase family income, this group of housewives deserves to be partners in the Community Partnership Program (PKM).

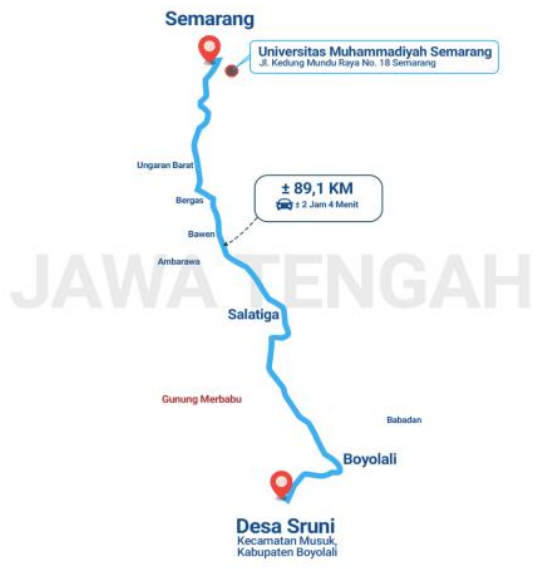

Figure 1. Location of Sruni Village, Musuk Sub-district, Boyolali Regency on map along with the distance from institution of educators involved in the education activity 
Based on a preliminary interview with community leaders in the village of Sruni, most of the farmers in the village of Sruni sell cow milk to the Village Unit Cooperation (KUD) in the form of fresh milk. Fresh milk production in Sruni Village is 20 liters per day, with a low selling price per liter of Rp. 5,000, -. There has been no attempt to process fresh milk into food products of higher economic value. This has resulted in the potential of the local natural resources of Sruni Village not to contribute to the maximum welfare of the community. The results of the SWOT analysis (strengths, weaknesses, opportunities, and threats) show that based on internal and external factors in Musuk Sub-district, Boyolali Regency has the potential to be developed for dairy cows (Santosa, Setiadi, \& Wulandari, 2013). Therefore, through the PKM program, community empowerment will be carried out by utilizing the potential of housewives in the village of Sruni through training in processing fresh cow's milk products into "ASI Yogurt" products.

The solution to overcome the situation in Sruni Village, Musuk, Boyolali shall be introducing process of transforming fresh milk into higher economic valued products to housewife community. This needs to be initiated by education to improve the knowledge and awareness about the importance of fermenting cattle milk into yogurt as a probiotic food product to obtain economic as well as health benefits. Such initiation step was done through a community education.

\section{METHODS}

A survey had been conducted at in March 2019 by the educators involving 2 students from Medical Laboratory Technology/Science and Food Technology Study Programs of Universitas Muhammadiyah Semarang. The follow-up meeting was subsequently done to plan and arrange education event including venue, operation and personnel. Finally, the education event was then conducted on April 28, 2019 as planned. It consisted of two sessions of seminars with facilities of power point media and printed material.

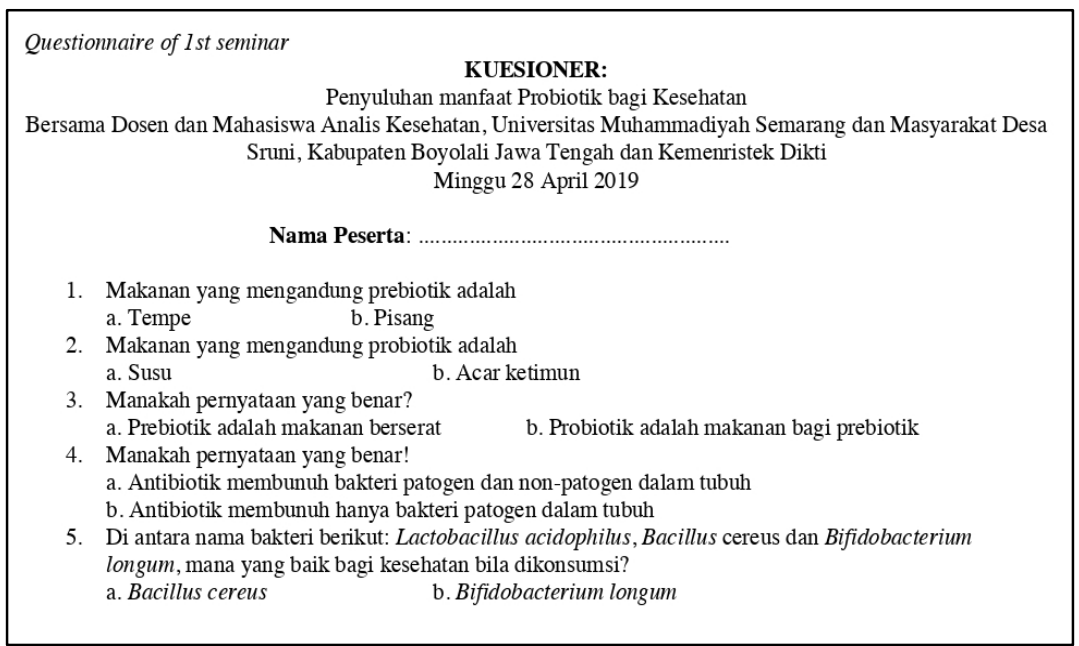

Figure 2. Questionnaire of the first-session seminar about health benefits of probiotics

The first seminar focusing on health benefit of probiotics including yogurt. Information was transferred to audience in a small class by Dr. Stalis Norma Ethica, M.Si., a lecturer at Medical Laboratory Science, Magister Study Program, Universitas Muhammadiyah Semarang (UNIMUS), with her food biotechnology expertise. The 
lecture was given for approximately 20 minutes and followed by a question and answer session for 10 mins. Prior and after the seminar, participants were asked to fill out a 5question questionnaire (Figure 2) containing questions about health benefits of probiotics.

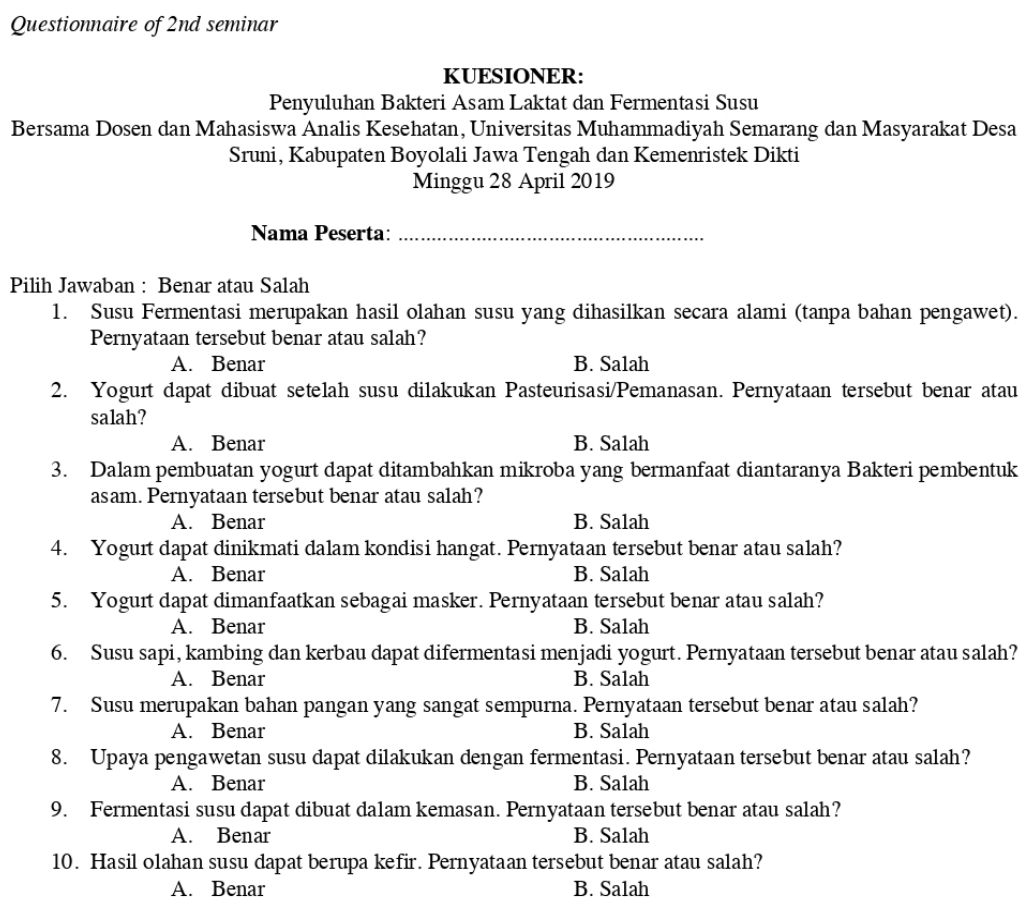

Figure 3. Questionnaire of the second-session seminar about health benefits of probiotics

The second seminar focused on economic benefits and the making process of yogurt. The subjects of this activity were 12 people. Information was transferred to audience also in a small class by Ms. Sri Sinto Dewi M.Si., a lecturer at Medical Laboratory Technology Study Program, UNIMUS, with expertise in microbiology. The presentation was 20 mins followed by a 10-min question and answer session. Prior and after the seminar, participants were asked to fill out a 10-question questionnaire (Figure 3) about economic benefits of yogurt as a fermented food product.

In both seminars, education was provided through a power point media, supported by printed materials. The activity was carried out at the house of housewife community of Sruni Village, Musuk Sub-district, Boyolali Regency, Central Java. The success indicator of the activity is increased awareness of the subjects about benefits of fermenting cattle milk into yogurt as a probiotic food product. The awareness was indicated by higher percentage of correct answers given by participants based on questionnaire-answer analysis before and after seminar. At the end of session, and milk sterilization and bacterial cultivation demo practice to make yogurt was provided.

\section{RESULT AND DISCUSSION}

Socialization of the benefits of fermenting cattle milk into yogurt as a probiotic food product for Sruni Village Housewife Community at Musuk, Boyolali had been done on April 28, 2019. Prior survey and meeting had been done as planned. The core education event was successfully done consisting of 2 small-class seminars ended with sterilization 
demo bacterial cultivation demo (Figure 4). As seen in Figure 4, both sessions were supported by power point media and printed material ended by sterilization and bacterial cultivation demo to make yogurt.

Participants of the sessions were 14 people consisting of 12 housewives living at Sruni Village and 2 students from Medical Laboratory Technology/ Science and Food Technology Study Programs of UNIMUS. The participants showed high enthusiasm during the event. It was indicated by good interaction between presenters and the participants, particularly in question-and-answer session. Another form of enthusiasm was the request from participant to extend discussion time longer than the arranged schedule.

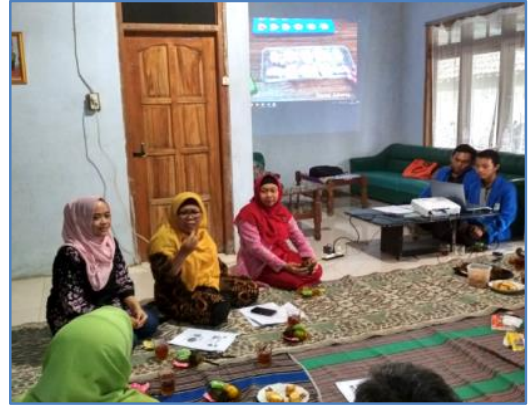

A

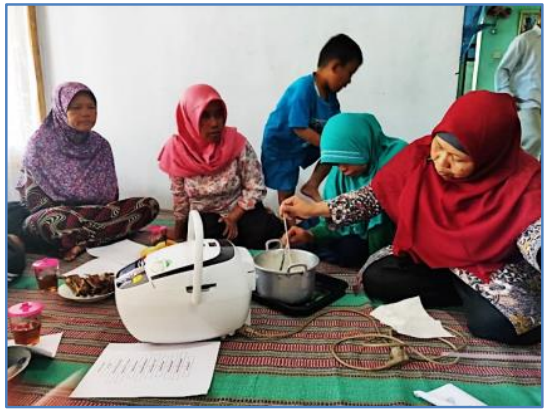

C

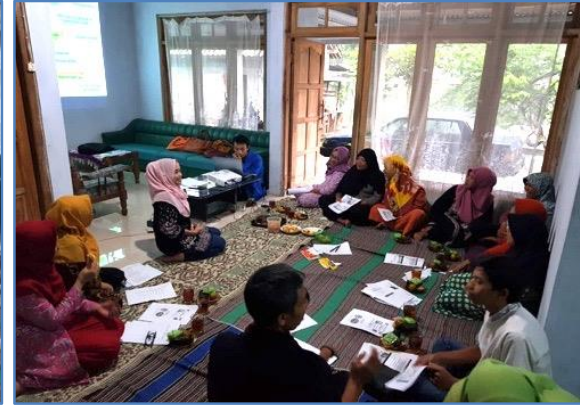

B

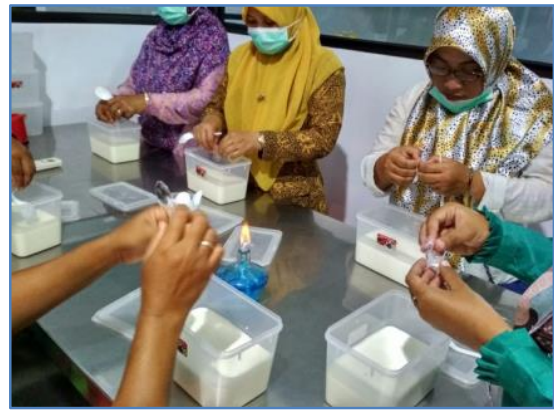

$\mathrm{D}$

Figure 4. Education event with housewife community at Sruni Village. A. Small-class presentation by lecturer using power point media supported by printed material. B. Discussion session engaging presenters, participants and students. C. Milk sterilization practice. D. Yogurt making demo

In both subsequent seminars, questionnaire was given at the beginning and the end session. In the first seminar, 5-question questionnaire contained topics listed in Table 1. Data of recorded answers on the questionnaire based on question number 1-5 (Table 1) were displayed as percentage in histogram (Figure 2). The histogram represented portion of correct answers given by each participant for each question of the questionnaire.

Table 1. List of questions in first seminar

\begin{tabular}{cl}
\hline Question Number & Topics \\
\hline 1 & Definition of prebiotics \\
\hline 2 & Definition of probiotics \\
\hline 3 & Differences between prebiotics and probiotics \\
\hline 4 & Influence of antibiotics towards microflora in human body \\
\hline 5 & Groups of pathogenic and nonpathogenic bacteria \\
\hline
\end{tabular}




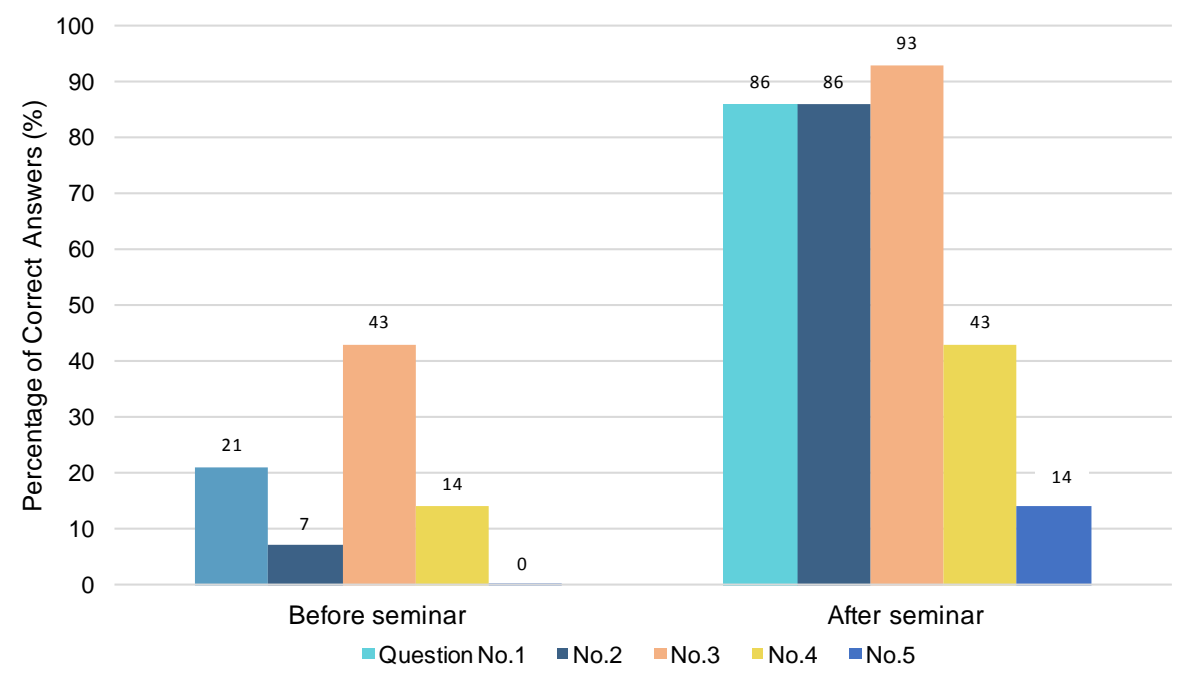

Figure 5. Percentage comparison of number of correct answers on questionnaire given before and after the first seminar

As seen in Figure 5, the first seminar produced in average 47.4\% improved answers in all questions given. Question number 5 showed that from zero knowledge about bacterium beneficial as probiotic, $100 \%$ participants could name Bifidobacterium longum and differentiate it from pathogenic one, Bacillus cereus.

In the second seminar, the 5-question questionnaire contained topics listed in Table 2. Data of recorded answers before and after seminar based on question number 1-10 (Table 2) were displayed as comparison of percentage also in histogram (Figure 3) representing portion of correct answers given by each participant for each question of the questionnaire.

Table 3. List of questions in the second seminar

\begin{tabular}{cl}
\hline Question Number & Topics \\
\hline 1 & Fermentation process of cattle milk into yogurt \\
\hline 2 & Process of yogurt making \\
\hline 3 & Process of yogurt making \\
\hline 4 & Yogurt serving \\
\hline 5 & Benefit of yogurt \\
\hline 6 & Materials used to prepare yogurt \\
\hline 7 & Benefit of milk \\
\hline 9 & Fermentation as preservation of milk \\
\hline 10 & Milk fermentation \\
\hline
\end{tabular}




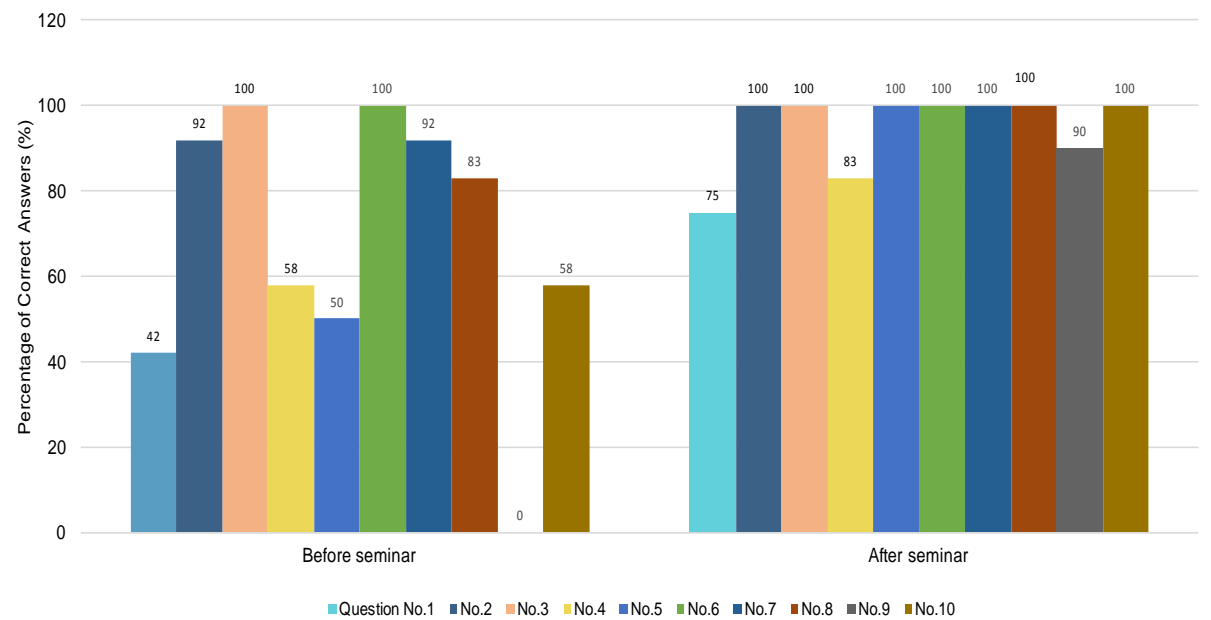

Figure 6. Comparison of number of correct answers questionnaire given before and after the first seminar

\section{CONCLUSION}

Based on Figure 6, the second seminar could generate in average $27.3 \%$ improved answers from participant of all 10 questions given. It could be seen from two histograms (Figure 4 and 5) that the first seminar provided lower number of questions (5) compared to the second one (10). Yet, it appeared that the first seminar, which was related with understanding of yogurt as probiotics and its health benefits, could provide more improvement on correct answers from its participants.

\section{ACKNOWLEDGMENT}

All authors cordially thank to Sruni villagers as participants in the community service activity and to LPPM Universitas Muhammadiyah Semarang for facilitating transportation to visited rural areas. This work is financially supported by or Community Partnership Grant or Hibah PKM (Program Kemitraan Masyarakat) by Ministry of Research and Higher Education of Indonesia (Kemenristek Dikti) 2019.

\section{REFERENCES}

Astuti, W. A., \& Musiyam, M. (2009). Kemiskinan dan perkembangan wilayah di Kabupaten Boyolali. Forum Geografi, 23(1), 71-85.

Dewi, R. F. (2016). Evaluasi sistem penyaluran raskin oleh perum bulog sub divre III Surakarta dalam upaya memenuhi kebutuhan pangan bagi masyarakat berpenghasilan rendah di Kabupaten Boyolali (Doctoral dissertation). Surakarta: Universitas Sebelas Maret. 
Herawati, D. (2013). Sumbangan usaha peternak sapi perah terhadap tingkat pendapatan rumah tangga di Kecamatan Musuk Kabupaten Boyolali (Doctoral dissertation) Semarang: Universitas Negeri Semarang.

Kartika, A. N. (2017). Wisata peternakan dan pengolahan susu sapi di Boyolali (Doctoral dissertation). Semarang: Universitas Diponegoro.

Kurniawati, L. (2017). Analisis penerapan bantuan pangan non tunai dan evaluasi sistem pelaksanaannya di Kota Surakarta (Doctoral dissertation). Surakarta: Universitas Sebelas Maret.

Ningrum, A. S. (2016). Kontribusi pendapatan usaha ternak sapi perah terhadap total pendapatan rumah tangga di Desa Singosari dan Desa Sruni Kabupaten Boyolali Provinsi Jawa Tengah. Geo Educasia-S1, 1(3), 1-8.

Nurtini, S., \& Anggriani UM, M. (2018). Profil peternakan sapi perah rakyat di Indonesia. Yogyakarta: UGM Press.

Putera, A. D. (2018). BPS: Maret 2018, persentase kemiskinan Indonesia terendah sejak 1999. Retrieved August 21, 2019, from https://bit.ly/359WrwD

Rachman, B., \& Agustian, A. (2018). Efektivitas dan perspektif pelaksanaan program beras sejahtera (Rastra) dan bantuan pangan non-tunai (BPNT). Analisis Kebijakan Pertanian, 16(1), 1-18.

Retnaningsih, N., \& Basuki, J. S. (2017). Strategi kemitraan antara KUD Musuk dengan peternak dalam meningkatkan pendapatan dan kesejahteraan peternak sapi perah di Kabupaten Boyolali. Journal Agrisaintifika, 1(1), 1-8.

Santosa, S. I., Setiadi, A., \& Wulandari, R. (2013). Analisis potensi pengembangan usaha peternakan sapi perah dengan menggunakan paradigma agribisnis di Kecamatan Musuk Kabupaten Boyolali. Buletin Peternakan, 37(2), 125-135.

Suswadi., \& Sutarno. (2018). Analisis pendapatan dan efisiensi usahatani padi organik di Desa Dlingo Kecamatan Mojosongo Kabupaten Boyolali. Proceeding of The URECOL, $400-416$.

Wicaksono, A., \& Sudarwanto, M. (2017). Peningkatan kualitas susu peternakan rakyat di Boyolali melalui program penyuluhan dan pendampingan peternak sapi perah. Agrokreatif Jurnal Ilmiah Pengabdian kepada Masyarakat, 2(2), 55-60. 